(Teknologi Rekayasa Jaringan Telekomunikasi) : Jurnal Teknik Elektro

Volume 1, Nomor 1, April 2021,

DOI: https://doi.org/10.51510/trekritel.v1i1.396

\title{
Analisis Perbandingan Kualitas Jaringan 4G LTE Operator X Dan Y Di Wilayah Kampus Utama UMSU
}

\author{
Noorly Evalina, Partaonan Harahap, A. Rendi Adrian \\ Program Studi Teknik Elektro \\ Universitas Muhammadiyah Sumatera Utara \\ Jl. Kapt. Muchtar Basri No.3 Medan, Indonesia \\ e-mail: noorlyevalina@umsu.ac.id
}

\begin{abstract}
Abstrak - Seiring berkembangnya era globalisasi saat ini, kebutuhan manusia akan bidang telekomunikasi juga semakin meningkat dan khususnya pada bidang telekomunikasi. Dengan pesatnya perkembangan membuat masyarakat khusus nya mahasiswa memerlukan suatu teknologi yang dapat mendukung transfer data dengan kecepatan tinggi dan dapat mendukung semua fitur layanan yang dibutuhkan. Muncul suatu teknologi yaitu Long Term Evolution (LTE) yang merupakan teknologi jaringan seluler generasi keempat (4G). LTE ini dapat memberikan kecepatan dalam hal transfer data mencapai $100 \mathrm{Mbps}$ pada sisi downlink dan 50 Mbps pada sisi uplink. Pertumbuhan jumlah pengguna layanan telekomunikasi di Kota Medan menyebabkan penurunan kualitas jaringan khususnya teknologi 4G LTE. Dengan dilakukan drive test dapat diketahui daerah dimana terdapat kekuatan sinyal suatu jaringan yang bertujuan untuk meningkatkan kualitas sinyal suatu jaringan. Benchmark (Perbandingan) kualitas layanan operator 4G LTE dilakukan dengan cara mengukur, membandingan, dan menganalisa kualitas jaringan (performansi) dari dua operator 4G LTE di sekitar kampus Universitas Muhammadiyah Sumatera Utara. Nilai keseluruhan throughput operator $X$ hanya $0>3 \mathrm{Mbps}$ sedangkan operator Y $0>30 \mathrm{Mbps}$. Nilai throughput yang sangat rendah di sebabkan oleh high traffic user pada waktu siang hari, dimana kampus Universitas Muhammadiyah Sumatra Utara sedang aktif perkuliahan dan banyak mahasiswa yang menggunakan layanan data. Dengan begitu, masyarakat dapat mengetahui penyebab terjadinya masalah kecepatan internet yang mereka rasakan saat menggunakan internet pada waktu siang hari.
\end{abstract}

Kata kunci : LTE, 4G, Drive Test Enginnering, Benchmarking, Telekomunikasi

Abstract-Along with the development of the current era of globalization, the human need for telecommunications is also increasing, and especially in the telecommunications sector. With the rapid development, students especially need a technology that can support high-speed data transfer and can support all the required service features. A technology appears, namely Long Term Evolution (LTE), which is a fourth generation (4G) cellular network technology. This LTE can provide data transfer speeds of up to $100 \mathrm{Mbps}$ on the downlink side and $50 \mathrm{Mbps}$ on the uplink side. The growth in the number of telecommunication service users in Medan City has caused a decline in network quality, especially $4 \mathrm{G}$ LTE technology. By doing a drive test, it can be seen the areas where there is signal strength of a network which aims to improve the signal quality of a network. Benchmark (comparison) of 4G LTE operator service quality is done by measuring, comparing, and analyzing the network quality (performance) of two 4G LTE operators around the Muhammadiyah University of North Sumatra campus. The overall throughput value of operator $X$ is only $0>3 \mathrm{Mbps}$, while operator $Y$ is $0>30 \mathrm{Mbps}$. The very low throughput value is caused by high traffic users during the day, where the Muhammadiyah University of North Sumatra campus is actively studying and many students use data services. That way, people can find out the causes of the internet speed problems they feel when using the internet during the day.

Keywords : $\quad$ LTE, 4G, Drive Test Engineering, Benchmarking, Telecommunications 


\section{Pendahuluan}

Seiring berkembangnya era globalisasi saat ini, kebutuhan manusia akan bidang telekomunikasi juga semakin meningkat dan khususnya pada bidang telekomunikasi. Dengan pesatnya perkembangan membuat masyarakat khusus nya mahasiswa memerlukan suatu teknologi yang dapat mendukung transfer data dengan kecepatan tinggi dan dapat mendukung semua fitur layanan yang dibutuhkan.

Muncul suatu teknologi yaitu Long Term Evolution (LTE) yang merupakan teknologi jaringan seluler generasi keempat (4G) yang distandarisasi oleh 3GPP (Third Generation Partnership Project).LTE merupakan kelanjutan teknologi 3G dan 3,5G dari pengembangan dari teknologi sebelumnya yaitu Universal Mobile Telecommunication System (UMTS) dan High-Speed Downlink Packet Access (HSPA). Pada UMTS, kecepatan transfer data maksimum adalah 2 Mbps, pada HSPA kecepatan transfer data mencapai 14,4 Mbps pada sisi downlink dan 5,6 Mbps pada sisi uplink, sedangkan pada LTE ini dapat memberikan kecepatan dalam hal transfer data mencapai 100 Mbps pada sisi downlinkdan $50 \mathrm{Mbps}$ pada sisi uplink[1]. Pertumbuhan jumlah pengguna layanan telekomunikasi di Kota Medan menyebabkan penurunan kualitas jaringan khususnya teknologi 4G. Dengan dilakukan drive test dapat diketahui daerah dimana terdapat kekuatan sinyal suatu jaringan yang bertujuan untuk meningkatkan kualitas sinyal suatu jaringan.Dalam pembuatan tugas akhir ini langkah-langkah yang diambil dalam pengumpulan data menggunakan drivetest tools yaitu seperti PCI (Physical Cell Id), RSRP (Reference Signal Received Power), SINR (Signal to Interference Noise Ratio), Throughput Downlink.Berdasarkan hal tersebut diatas, penulis berkeinginan membuat tugas akhir tentang "Analisis Perbandingan Kualitas Jaringan 4G LTE Operator X dan $Y$ di Wilayah Universitas Muhammadiyah Sumatera Utara". Benchmark (Perbandingan) kualitas layanan operator 4G LTE dilakukan dengan cara mengukur, membandingan, dan menganalisa kualitas jaringan (performansi) dari dua operator 4G LTE di sekitar kampus Universitas Muhammadiyah Sumatra Utara.Benchmark kualitas layanan untuk data ini didapat dari hasil Drivetest Engineering dan mengacu pada KPI (Key Performance Indicator), yaitu Serving PCI, RSRP (dBm), SINR (dB), Throughput Downlink and Uplink (Mbps).Dari hasil benchmark yang diperoleh nanti dapat diketahui kualitas layanan (performansi jaringan) operator mana yang memiliki kualitas sinyal paling bagus untuk area Medan khususnya area sekitar Kampus Universitas Muhammadiyah Sumatra Utara. Selain itu juga dapat diketahui permasalahan performansi jaringan yang dirasakan secara langsung dari sisi pelanggan.

\section{STUdi PUSTAKA}

\section{A. Teknologi $4 G$}

4G merupakan generasi yang keempat yang mulai dikenalkan pada 2009, Penemu teknologi LTE adalah Khoirul Anwar asal Indonesia yang telah menetap di Jepang selama 12 tahun dan menjadi peneliti di JAIST (Japan Advanced Institute of Science and Technology School of Information Science).Teknologi seluler ini disebut LTE (Long Term Evolution) dan juga LTE-A (Long Term Evolution Advance) Teknologi LTE ini mempunyai kecepatan DL sampai 100 Mbps dan UL sampai 50 Mbps. Kecepatan itu masih bisa menjadi jauh lebih cepat lagi sesuai rilis kategori yang dipakai oleh operator tersebut.4G adalah singkatan dari istilah dalam bahasa Inggris: fourth-generation technology. Nama resmi dari teknologi 4G ini menurut IEEE (Institute of Electrical and Electronics Engineers) adalah "3G and beyond". Sebelum 4G, High-Speed Downlink Packet Access (HSDPA) yang kadang kala disebut sebagai teknologi 3,5G telah dikembangkan oleh WCDMA sama seperti EV-DO mengembangkan CDMA 2000. HSDPA adalah sebuah protokol telepon genggam yang memberikan jalur evolusi untuk jaringan Universal Mobile Telecommunications System (UMTS) yang akan dapat memberikan kapasitas data yang lebih besar[2].

\section{B. Drive Test}

Drive Test merupakan salah satu bagian pekerjaan dalam optimasi jaringan radio. Drive test bertujuan untuk mengumpulkan informasi jaringan secara nyata di lapangan. Informasi yang dikumpulkan merupakan kondisi aktual Radio Frequency (RF) di suatu eNodeB[3].

Copyright $^{\oplus} 2021$ TRekRiTel (Teknologi Rekayasa Jaringan Telekomunikasi) : Jurnal Teknik Elektro. This is an open acces article under the CC-BY-SA lisence (https://creativecommons.org/licenses/by-sa/4.0/). 


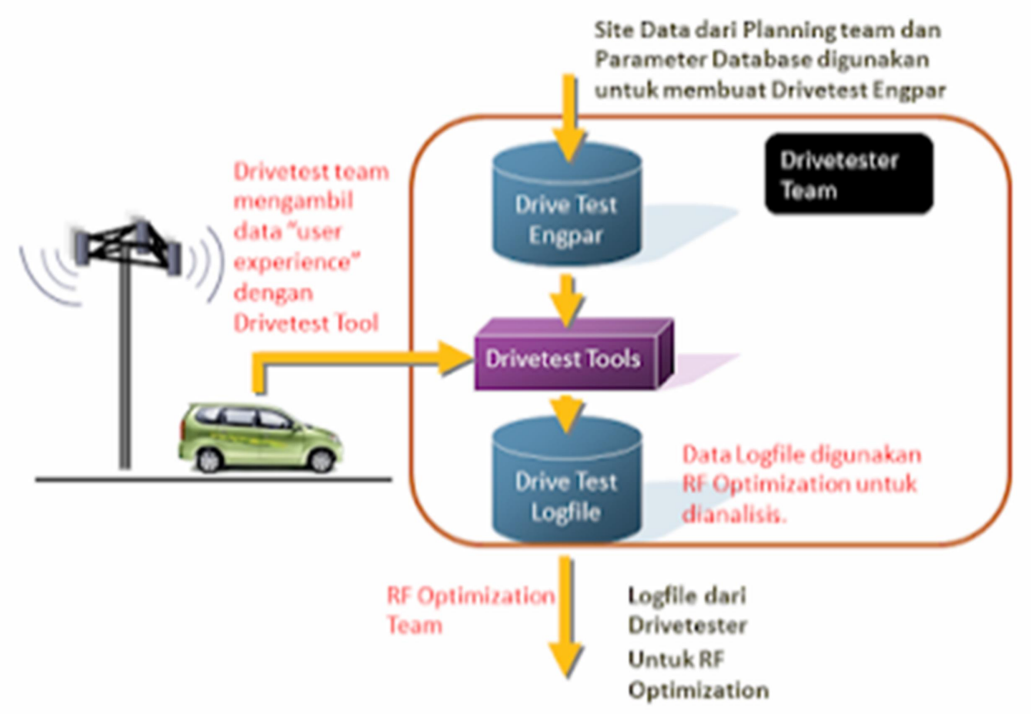

Gambar 1. Proses Drive Test

C. Parameter Drive Test

1. PCI (Physical Cell ID) merupakan cara untuk mengidentifikasi pada fisik cell dalam jaringan LTE. Setiap cell melakukan broadcast penandaan identifikasi berupa PCI yang digunakan oleh perangkat untuk mengidentifikasi cell (melibatkan frekuensi dan waktu) dalam prosedur handover.

2. RSRP (Reference Signal Received Power) merupakan sinyal LTE power yang diterima oleh user dalam frekuensi tertentu semakin jauh jarak antara site dan user, maka semakin kecil pula RSRP yang diterima oleh user.

3. SINR merupakan rasio perbandingan antara sinyal utama yang dipancarkan dengan interferensi dan noise yang timbul (tercampur dengan sinyal utama).

4. Throughput adalah bandwidth aktual yang terukur pada suatu ukuran waktu tertentu dalam suatu hari menggunakan rute internet yang spesifik ketika sedang mendownload suatu file.

\section{Benchmark}

Benchmark adalah teknik pengetesan dengan menggunakan suatu nilai standar.Suatu program atau pekerjaan yang melakukan perbandingan kemampuan dari berbagai kerja dari beberapa provider dengan tujuan untuk meningkatkan kualitas pada produk yang baru. Pengujian dilakukan dengan cara membandingkan kualitas jaringan dari dua atau tiga operator dengan percobaan yang sama. Benchmark sendiri bertujuan untuk mengetahui dan membandingkan kualitas operator satu dengan yang lain agar dapat diketahui operator mana yang memiliki kualitas jaringan yang terbaik[4].

\section{METODE}

Adapun langkah-langkah metode penelitian ini, yaitu :

1. Studi Literatur

Meliputi studi definisi Drive Test Engineering and Benchmarking untuk mengetahui kualitas layanan operator 4G LTE yang di amati.

2. Pengumpulan Data

Meliputi pengambilan dan pengumpulan data yang didapat dengan mengambil sampel langsung di Area Kampus Universitas Muhammadiyah Sumatera Utara. 
3. Pengolahan Data dan Analisa

Menganalisis hasil data yang telah di ambil di lapangan dengan menggunakan metode Drive Test yang berdasarkan data aktual yang ada sehingga didapat nilai-nilai atau parameter-parameter yang dimaksud serta data tersebut dapat juga disajikan dalam bentuk grafik.

a. Jalannya Penelitian

1. Penelitian dilakukan melalui beberapa tahap pengukuran dan analisa data sebagai berikut :

2. Pertama-tama mempersiapkan Alat (Laptop, MS/UE/Headset, GPS) dan Bahan (Aplikasi Probe v3.17 dan Assistant v3.17, serta driver baik untuk MS dan GPS, serta Microsoft Network Monitor).

3. Alat yang diperlukan antara lain Laptop dengan Spec Minimal Core i3, RAM Minimal 4 GB, MS (Mobile Station), UE (User Equipment), Samsung S5, GPS Receiver.

4. Bahan yang diperlukan antara lain, Aplikasi Genex Probe v3.17, Aplikasi Genex Assistant v3.17, Driver UE Samsung Driver dan Microsoft Network Monitor.

5. Setelah persiapan alat dan bahan sudah, maka selanjutnya buka program Probe v3.17 dengan cara klik 2x pada shortcut program Probe,

6. Di putaran pertama kita ambil data Operator $X$ dahulu dengan menggunakan program tersebut.

7. Lalu di putaran kedua kita ambil data Operator $Y$ dengan menggunakan program tersebut.

8. Setelah semua data yang di inginkan sudah dapat, lalu kita gunakan Genex Assistant v3.17 untuk menganalisa data yang telah kita ambil di lapangan.

9. Lalu tampilkan data PCI, RSRP, SINR, dan Throughput padan Genex Assistant v3.17 dari kedua operator tersebut.

Setelah data di ambil dan di kumpulkan, lalu kita bandingkan dengan tabel perbandingan[5].

\section{Hasil Dan PeMbahasan}

Datapenelitian diambil di sekitaran Kampus Utama Universitas Muhammadiyah Sumatra Utara tepatnya di Jl. Kapten Muchtar Basri No. 3, Glugur Darat II, Kota Medan, Sumatra Utara.

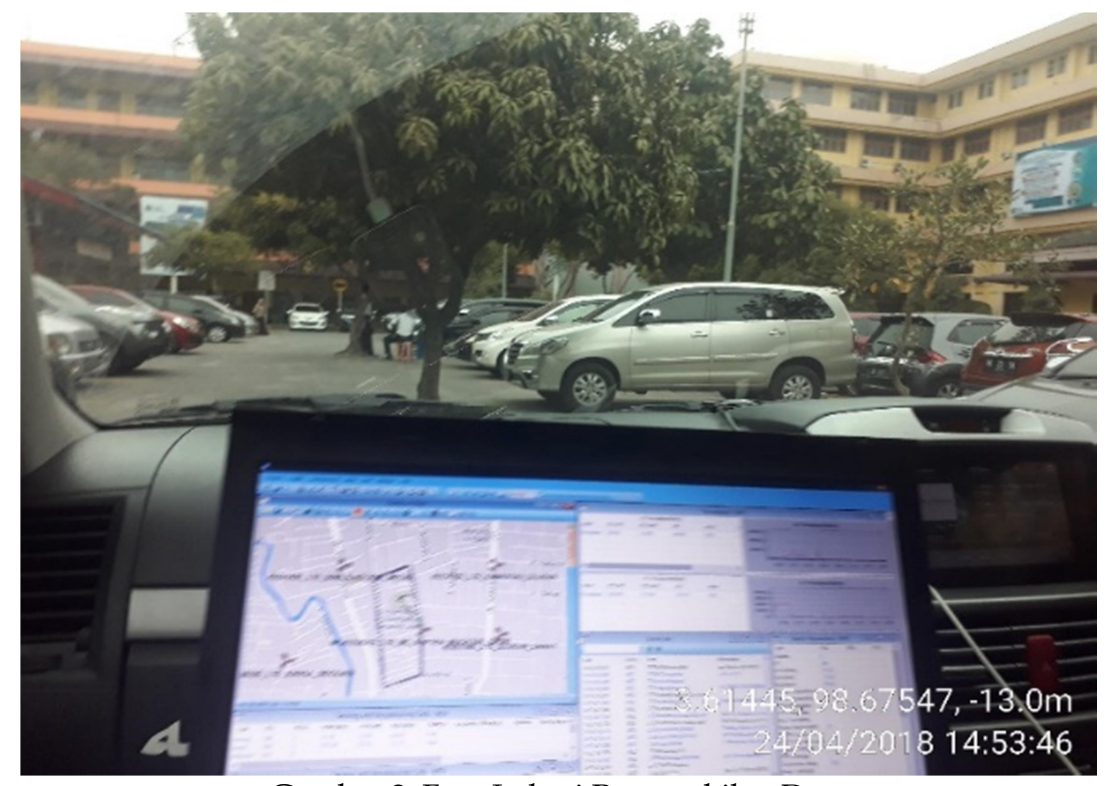

Gambar 2. Foto Lokasi Pengambilan Data

Setelah dilakukan pengambilan data pada drive test di lapangan, perbandingan data yang diperoleh sebagai berikut 


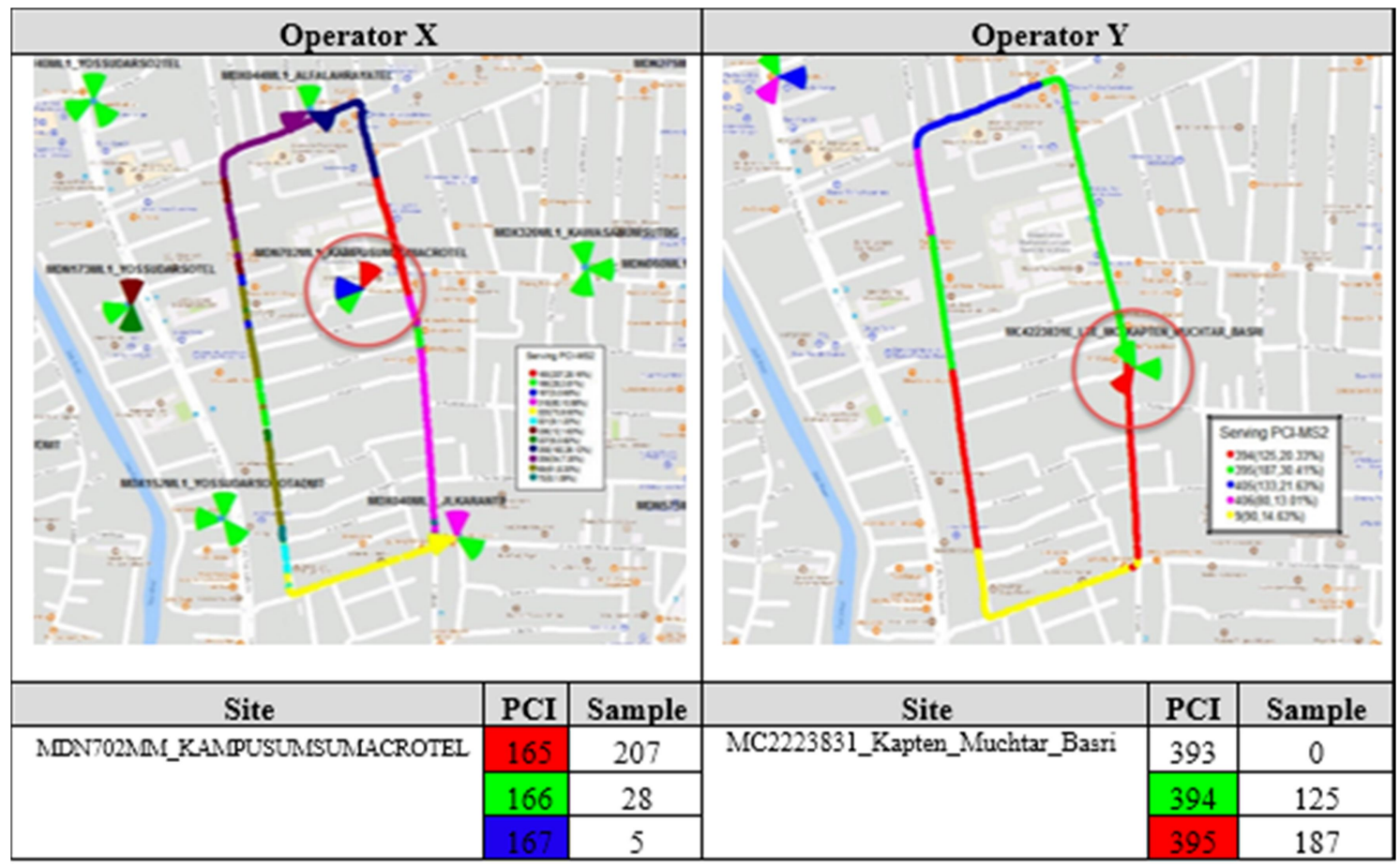

Gambar 3. Tabel Perbandingan PCI

Dari gambar di atas bisa kita lihat kampus Universitas Muhammadiyah Sumatra Utara di cover oleh site MDN702MM_KAMPUSUMSUMACROTEL milik operator $X$ dan site MC2223831_Kapten_Muchtar_Basri milik operator Y. Dengan begitu kita dapat mengetahui site mana yang mengcover kita pada saat berada di kampus Universitas Muhammadiyah Sumatra Utara.

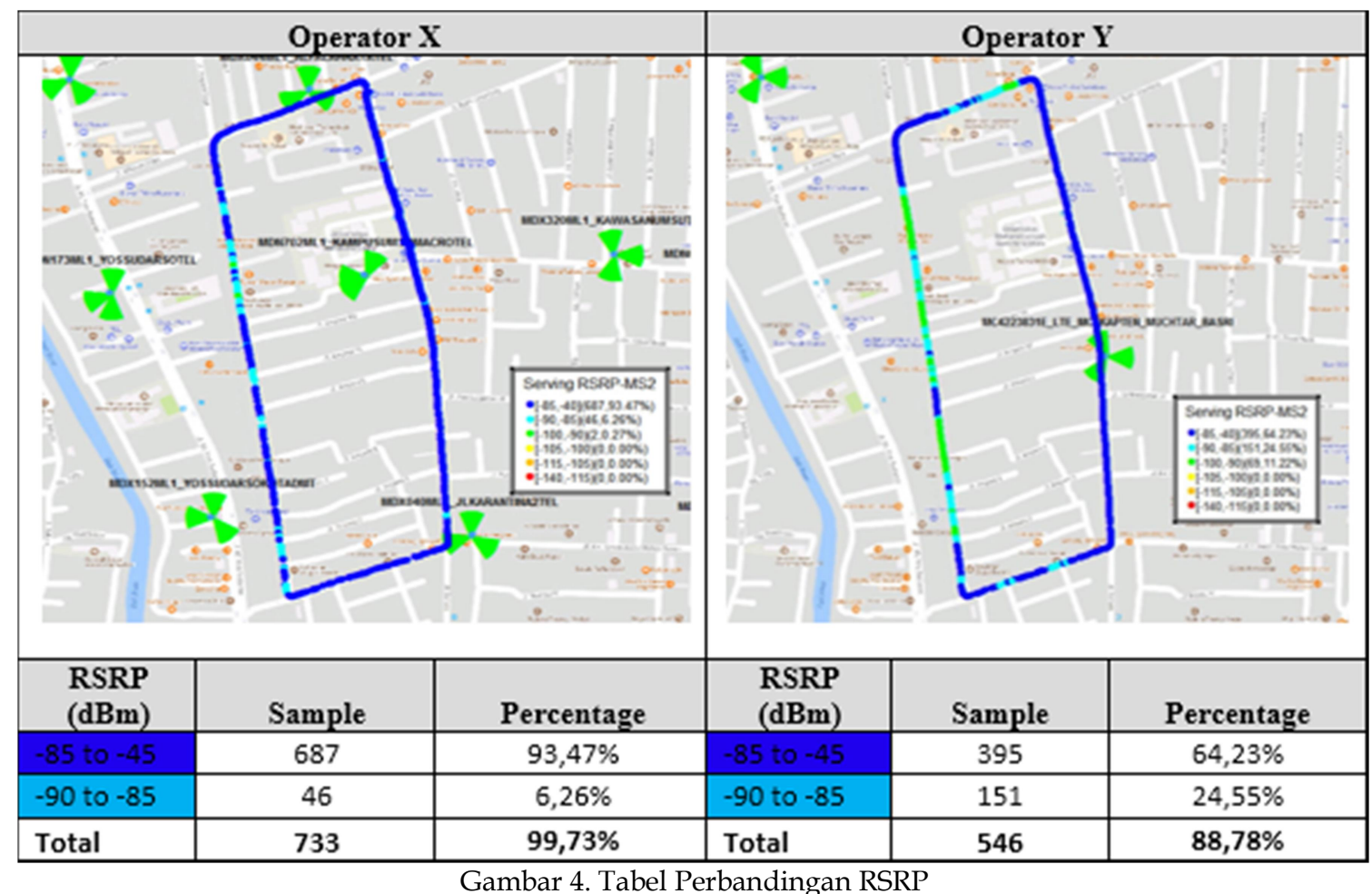

Distribusi RSRP Operator $X$ di area kampus Universitas Muhammadiyah Sumatera utara memiliki persentasi $99,73 \%$ dengan sample 733 . Sedangkan Operator Y memiliki persentasi 88,78\% dengan sample 546. Semakin banyak sample yang di dapat maka semakin besar juga persentasi nya. 


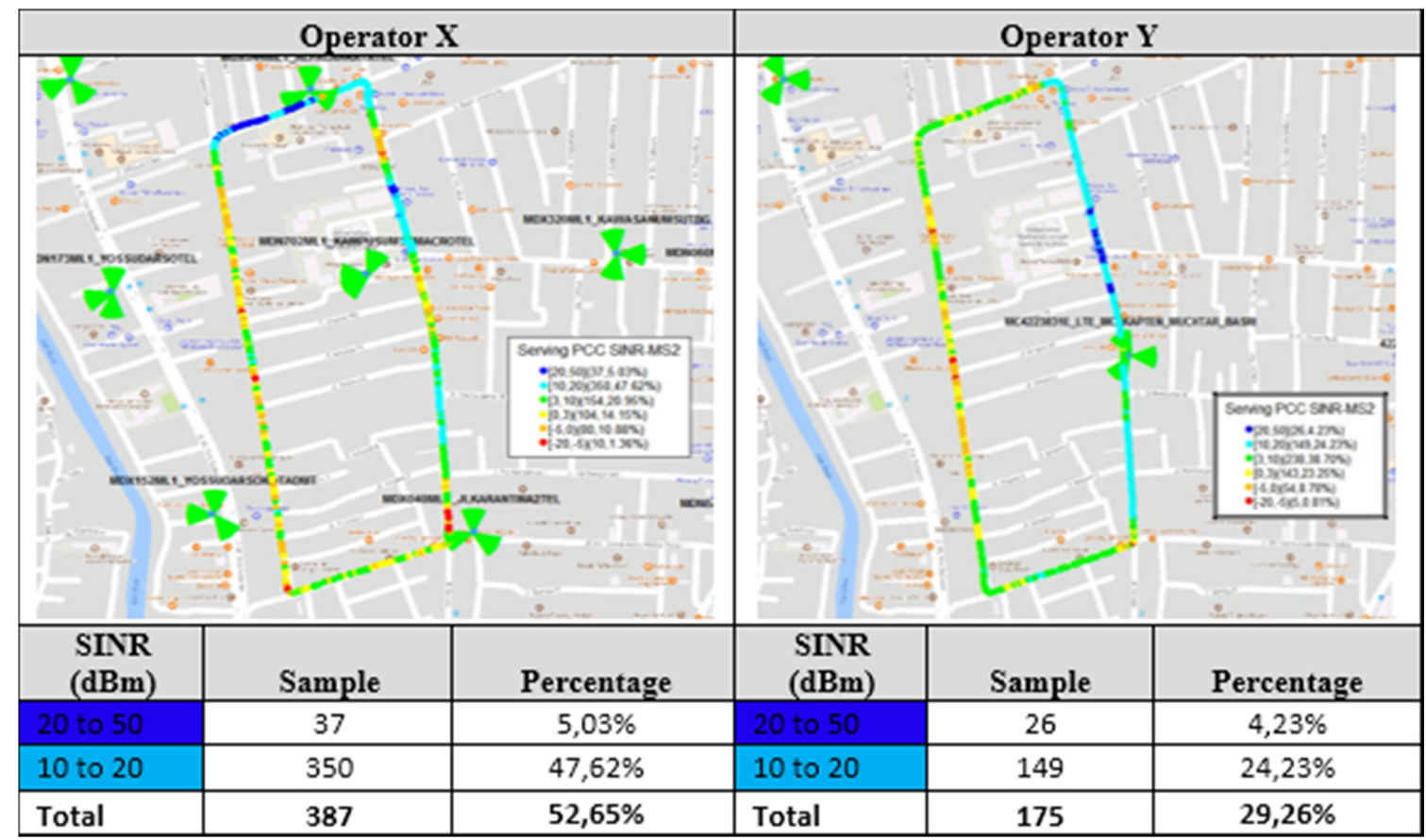

Gambar 5. Tabel Perbandingan SINR

Dari data di atas level SINR Operator X lebih dominan dengan persentasi 52,65\% dan 387 sample. Sedangkan Operator Y memiliki persentasi $29,26 \%$ dan 175 sample. Karena SINR sendiri sangat mempengaruhi kecepatan throughput, semakin banyak sample biru dalam hasil drive test maka sangat menentukan kecepatan throughput.

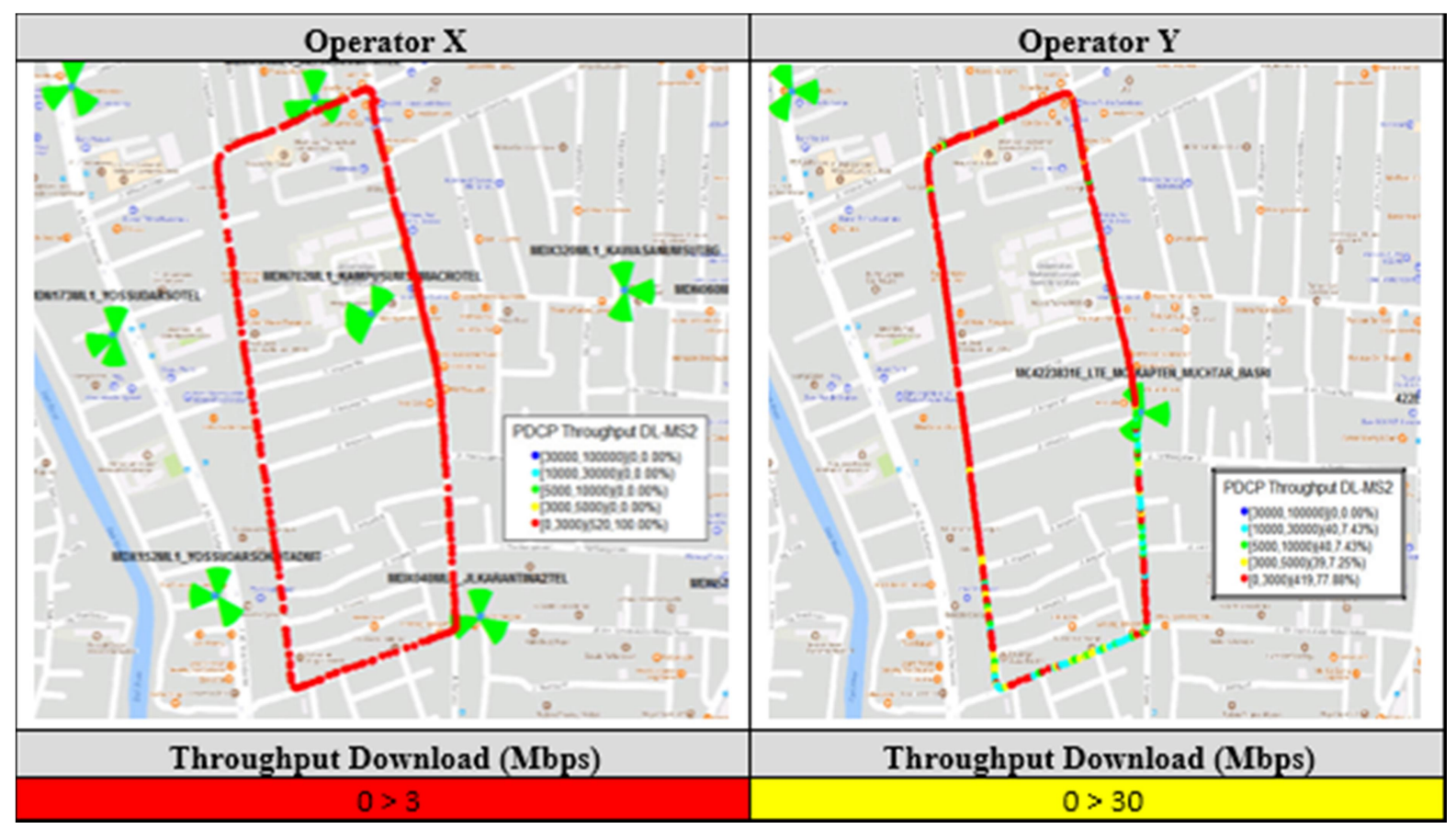

Gambar 6. Tabel Perbandingan Throughput

Berdasakan data yang sudah kita ambil, kecepatan download kedua operator tidak jauh berbeda. Throughput operator $X$ hanya $0>30$ Mbps sedangkan operator Y $0>30$ Mbps. Hasil data di atas bisa di bilang sangat jauh dari kata bagus, karena bisa kita lihat Tabel 4.10 kedua operator tersebut memiliki banyak sample data yang merah. Data tersebut di ambil dalam keadaan banyak pengguna di daerah tersebut. Hal itu bisa kita ketahui dari data tabel di bawah ini. 


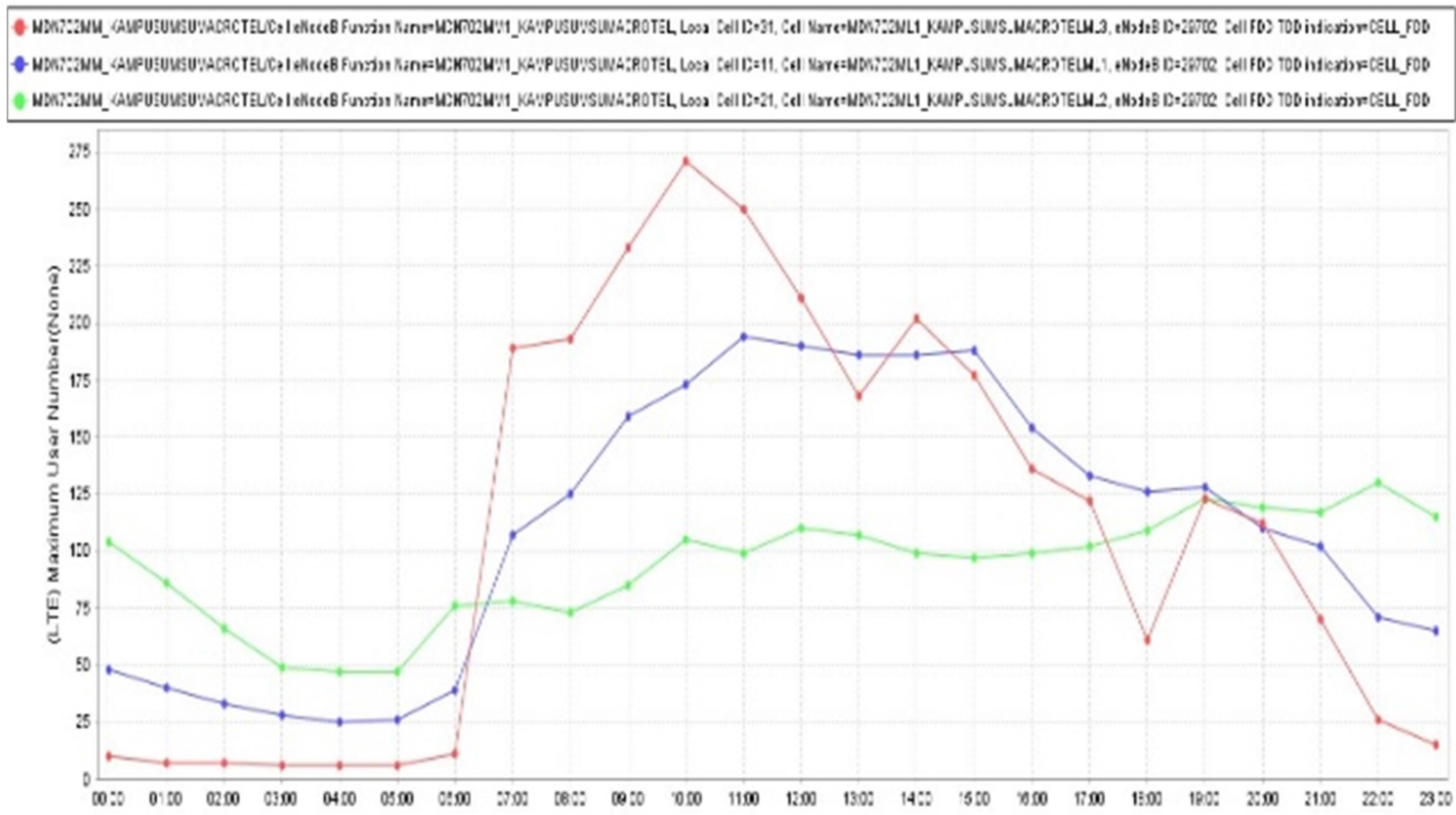

Gambar 7. Grafik User Operator X

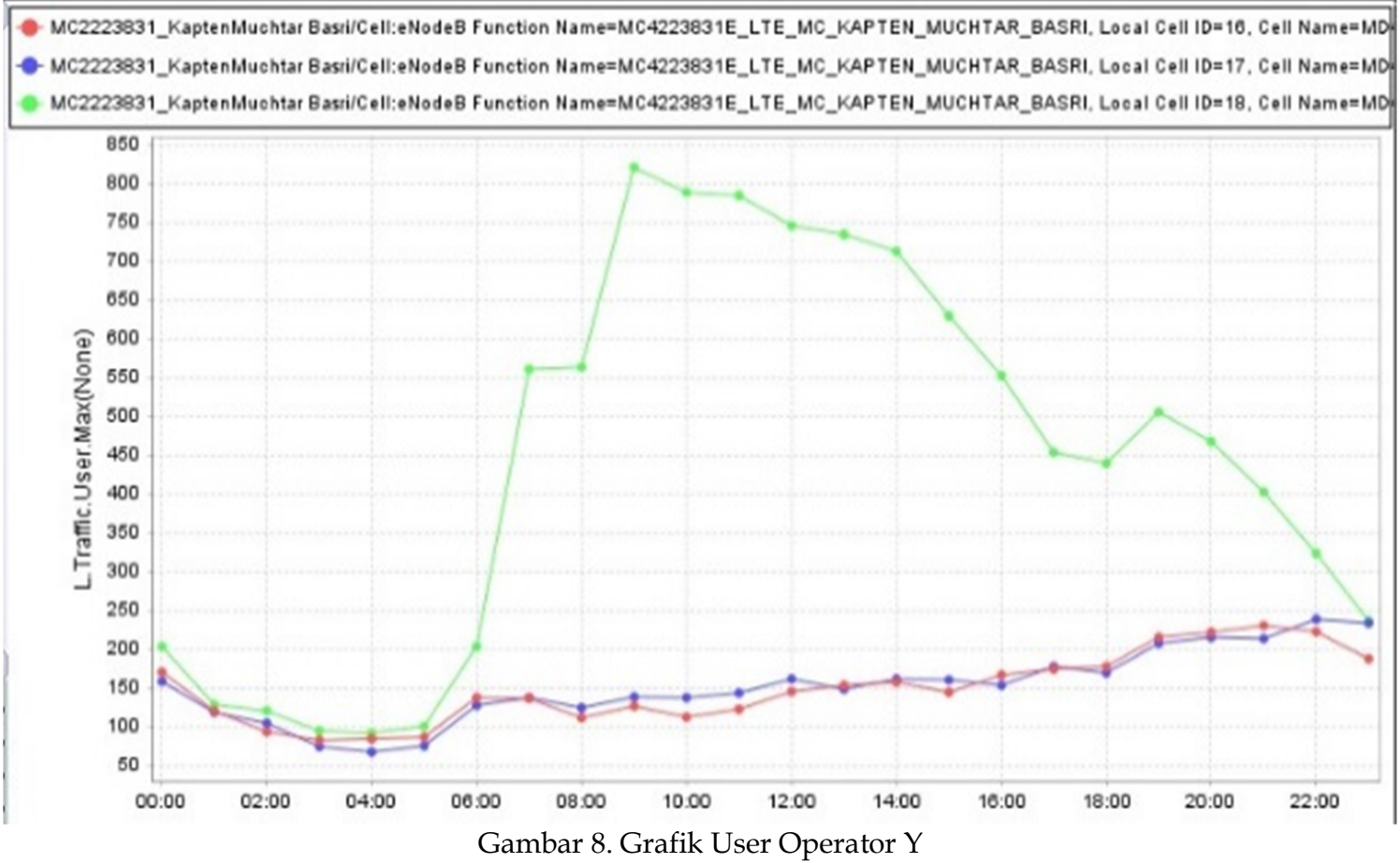

Menurut data grafik di atas pengguna pada saat pengambilan data yaitu tanggal 24 April 2018 Jam 15.00.Pengguna Operator $X$ dan $Y$ di atas 100 pengguna dalam satuan waktu. Sementara kapasitas antena dari kedua operator tersebut 100 pengguna dalam satuan waktu.Ini high traffic user yang menyebabkan koneksi internet yang kita rasakan jadi sangat lambat. Karena kita harus berbagi dengan pengguna lainnya dan dengan cara bergantian. 


\section{KESIMPULAN}

Hasil analisa data kualitas jaringan operator 4G LTE di Wilayah Kampus Universitas Muhammadiyah Sumatera Utara yang telah kita ambil adalah nilai keseluruhan operator $\mathrm{Y}$ pada parameter SINR memiliki rentang nilai 10>50 dBm, Dengan persentasi 52,65\% dan 387 sample. Sedangkan Operator Y memiliki persentasi $29,26 \%$ dan 175 sample. Dan semakin banyak sampling, maka semakin besar presentasinya. Nilai keseluruhan Throughput operator $X$ hanya $0>3 \mathrm{Mbps}$ sedangkan operator Y $0>30 \mathrm{Mbps}$.Tingkat performansi 2 (Dua) operator 4G LTE yang ada wilayah Kampus Utama UMSU berdasarkan data yang telah di ambil dan di analisa nilai throughput yang sangat rendah $0>3 \mathrm{Mbps}$ di sebabkan oleh high traffic user pada waktu siang hari, dimana kampus Universitas Muhammadiyah Sumatera Utara sedang aktif perkuliahan dan banyak mahasiswa yang menggunakan layanan data.

\section{DAFTAR PUSTAKA}

[1] S. Suyuti, Rusli, and S. Syarif, "Studi Perkembangan Teknologi 4G - LTE dan WiMAX Di Indonesia," J. Ilm. UNHAS, vol. 09, no. 02, pp. 60-65, 2011.

[2] F. Fauzi, G. S. Harly, and H. Hs, "Analisis Penerapan Teknologi Jaringan LTE 4G Di Indonesia," vol. 10, no. 2, pp. 281-290, 2014.

[3] D. Bagus and F. R. Adian, "Aplikasi Tems Investigation Sebagai Tool Untuk Drive Test Pada Sistem," J. Elektron. dan Telekomunkasi, vol. 05, no. 02, 2007.

[4] A. P. Sari, L. Lidyawati, and A. R. D, "Analisis Benchmarking Jaringan 3G Operator HCPT dan XL di Area Jakarta," J. Online Inst. Teknol. Nas., vol. 1, no. 2, 2013.

[5] N. Wahyu, A. Setiawan, and H. Vidyaningtyas, "Optimization Of Data Service LTE Network With Genex Assistant In Delanggu Klaten," vol. 4, no. 3, pp. 3532-3539, 2017. 